\title{
The technology that meets modern human needs - criteria of assessment of smart home system
}

\author{
Dariusz Gaweł \\ https://orcid.org/0000-0001-5759-1962 \\ d.gawel@pollub.pl \\ Faculty of Civil Engineering and Architecture, Lublin University of Technology
}

\begin{abstract}
The article is a summary of the research conducted for educational purposes with the participation of students from the University of Technology in Lublin in Poland, on the design and use of facilities created as smart home (SH). The increasing availability of smart building equipment systems is associated with their widespread use and reasonable price. New technologies, which are the result of scientific and technological progress, make it possible to use the devices to raise the standard of habitation and use of buildings. The creation of SH facilities nowadays is not only limited to single-family buildings. More and more often we observe smart multi-family and public utility buildings. At the same time, we are aware of the design of energy self-sufficient facilities, which allow us the freedom to build in undeveloped areas.
\end{abstract}

Keywords: new technologies, human needs, SH smart home system

\section{Introduction}

Modern houses are built to meet the needs of their users and respond to the times in which we live. The idea of $\mathrm{SH}$ is not a recent one; the appearance of the first home appliances was not at all related to their smart operation. Few people know that the origins of the system can be traced back to the 1970s, when, in order to improve production technology in industrial plants in the United States, a set of devices was implemented to increase the level of quality control. Production monitoring translated into economic results; therefore, the system was quickly applied in other sectors of the economy [9]. Eventually, after achieving positive results, it could also be used for the purposes of single-family housing.

It has been noticed that the devices can efficiently replace people in coordinating the work of various complicated systems. Due to independent digital and technological monitoring, many people have become interested in this technology. Creators of subsequent devices complementing the system wanted to attract the maximum number of customers aware of the benefits resulting from use of them. The acceptance of these devices by their users could be evidenced by a whole range of products that appeared on the market known by the common name SH. Their price very often did not compensate for the benefits. The next stage of development was the creation of particular groups of devices, starting from simple household appliances. These systems were becoming more and more common. Not only lightbulbs were created, but many complex devices such as weather stations, heating devices, air conditioners, audio-video, or parking systems. As the demand grew, these products were quickly supplemented by smart plug sockets, cameras, alarm devices, or security systems for entire buildings (fire, evacuation, gas detectors, etc.) [8]. 
According to opinions gathered during a research conducted in 2019 by the independent market research company Cite Research on a representative group of 1,000 Americans, smart devices will be widely available in less than 10 years, i.e. by the end of the 2030s. In Poland, the idea of a smart home or smart appliances is only just starting to gain popularity. It is estimated that in buildings built in 2018 , smart devices were used in $23 \%$ of them [14].

\section{Creating contemporary smart home facilities}

The term "smart" has evolved in the very way we understand its meaning. "Smart" - what does that actually represent? Turning on and operating when it is needed, or when it is activated. A set of smart devices is supposed to provide comfort to a resident, but also increase the safety of operation, affect the work economy and energy consumption of other devices in the system [3]. The popularity of new systems is most often due to the possibility of using a virtual assistant, which is an advisor, or manager and observer of what we are not able to see and modify (because it happens on a digital plane). This is due to the connection of many devices in the system, a smart network of installations and subsystems [5].

Following the principle of economy, it is possible to monitor the installations of functionally complex buildings or even vast complexes of buildings. Smart building technology BMS (Building Management System) is often based on an integrated management system of installations with which it is equipped [9]. Such technology is used in hospitals, hotels, office buildings, shopping centres and malls and vast housing estates. BMS can be basically divided into:

- Open systems - allowing for connection and mutual communication of individual system elements; their basic feature is compatibility and availability to the public, also in servicing.

- Closed systems - based on technologies of selected manufacturers, used for particular functions, often designed exclusively for specialised installations.

Connecting these devices together in a system and automating them in order to optimise energy consumption or meet user requirements was supposed to allow us to make better use of the facilities already available in a building. It turns out that finding the optimal smart energy management system is becoming more and more challenging [6]. For many consumers, personalisation of the system remains an important asset. Despite the widespread use of wireless systems, many users still opt for a traditional cable connection, believing it to be more reliable.

\section{Smart home systems}

A set of smart home devices creates a personalised structure, with the primary task of improving user comfort (without the need to program these devices), thanks to the automatically adjusted interdependence of the work [12].

The basic classification of the SH system is related to the method of power supply of the facility; therefore, we divide it into cable and wireless systems. When designing a house with cable installations, we must anticipate the location of individual elements of the system and integrate them with the furniture in order to distribute the cabling under the plaster. Such cabling may prove troublesome, as changing the location of one element may result in the necessity to renovate the interiors. It is common for power cables to run through the building's structural elements, under the plaster or under finishing elements such as stone, mirror, or metal. However, the cable system has its supporters, due to its reliability and uninterrupted operation. The wireless system connects devices via a wireless WIFI network. One of the great advantages of this system is mobility, i.e., the possibility to change the configuration of individual devices. It works perfectly in open rooms without created partitions between them. In order to ensure proper functioning, good quality links with appropriate technical parameters are required [1]. 
Another division of the SH system differentiates the possibility of control of it; therefore, we divide it into:

- Centralised - where all component devices are connected to a central element controlling the operation. The only connection of the elements remains on the line - controlling centre - an element. In case of failure of the central controlling element, the system also fails.

- Decentralised - all the devices are connected to each other (without the central controlling element), in case of failure of one device, the other devices will operate excluding this one.

The SH system is most often controlled via WIFI (although there are also connections via Bluettooth or BLE) from connected devices, e.g., a smartphone via an appropriate application [10]. Earlier solutions included installation of an additional control element connected to the network, which would be placed in an accessible place, e.g., on the wall. Due to the increasing number of manufacturers of smart devices, it is important to remember to use a single brand in order to eliminate possible problems associated with the operation of the entire system (this is related to the use of different software by individual manufacturers).

\section{Challenges for the future}

The question for the near future is not "if" but "how" to specify the way in which smart technology systems (abbreviated as $\mathrm{SH}$, should be implemented\}. Overcoming the gap between the level of single-family houses and the level of public buildings and services is a very difficult challenge. Education of both consumers and designers and contractors seems to be necessary in this regard. This translates into the necessity to shape not only the building itself (as a solid figure), but also the natural environment exploited by its users. Nowadays, smart houses are not only a combination of technical solutions and application of the appropriate methods of their management: starting up, switching off, optimising of energy consumption, but also the possibility of connecting them to the system of ecological solutions [2]. It seems crucial to adjust the technological level of smart systems to the users' needs. Putting too many devices in a building may not appeal to their users. Too complicated devices and cumbersome maintenance may turn potential customers away from the system as an unnecessary extravagance that does not bring the expected benefits.

Modern construction should combine technological progress with integration of the building into the natural environment. Systems should not be limited to indoor equipment. Smart devices should also be used outside the building, e.g. for monitoring security systems, sprinkling and watering greenery, or identifying visitors. Providing appropriate conditions for investment and creation of smart building is becoming a driver of development [4]. Therefore, creation of new objects must be connected by coordination of planning and investor activities. At the same time, construction of such facilities on a wider scale must be recognised by local authorities, which should prepare in advance the necessary legal regulations and develop land with technical infrastructure for new investments.

\section{Method}

Research performed with a participation of students of the Faculty of Civil Engineering and Architecture of Lublin University of Technology (FCEA LUT), majoring in architecture, was aimed at determining the possibilities of applying and modifying the smart home system on a broader scale than single-family housing. The main focus of the research was to understand the problem and to further direct the work on expanding the possibilities of applying the SH system in different building configurations. As part of the module of classes on design, immediately before starting the project, students had to determine the possibilities of extending the evaluation criteria (use of the system), depending on the designed function of the building (while proposing alternative groups of criteria - relevant to the given function).

A group of 32 master's degree students participated in the study. Considering the number of students in their final semesters, one might say that this is a small representative group. Introduction and familiarisation with the issue has been made earlier within the framework of lecture classes, the results of which can be classified as important with regard to improving the level of education. The results of the research were to provide 
a theoretical basis for the technical design of a multi-family or public building equipped with SH systems. The format of the research was a short questionnaire in the form of 4 open-ended questions, allowing the respondents freedom of expression, depending on the complexity of the subject. This type of question structure called for a greater involvement of the author of the research in systematising and classifying the answers. The quantitative statistical method was used to systematise the answers, so the answers with the largest number of criteria listed by the respondents were taken into account. Therefore, the group of 5 most popular answers in each criterion was presented visually.

Scientific research in architecture usually concerns new technologies of construction and equipment of buildings, their effects in connection with the education of students can serve as a basic source of increasing the scientific potential and creating future scientific staff [11] The choice of research technique that scientists use in their research is crucial. Hence the decision to choose a clear statistical method through questionnaires, which allows for interesting results in qualitative research.

\section{Results of research and analysis}

Providing answers to the questions was supposed to familiarise students with the specifics of designing smart buildings. The first question was to determine to what extent the creation of new smart systems makes sense in buildings with a large flow of people and whether it is really justified. The negative and neutral answers allowed the author to identify the group of students partially convinced or unconvinced by this technology. As can be seen from the answers, the vast majority of respondents can clearly see the point and accept this form of constructing of smart buildings.

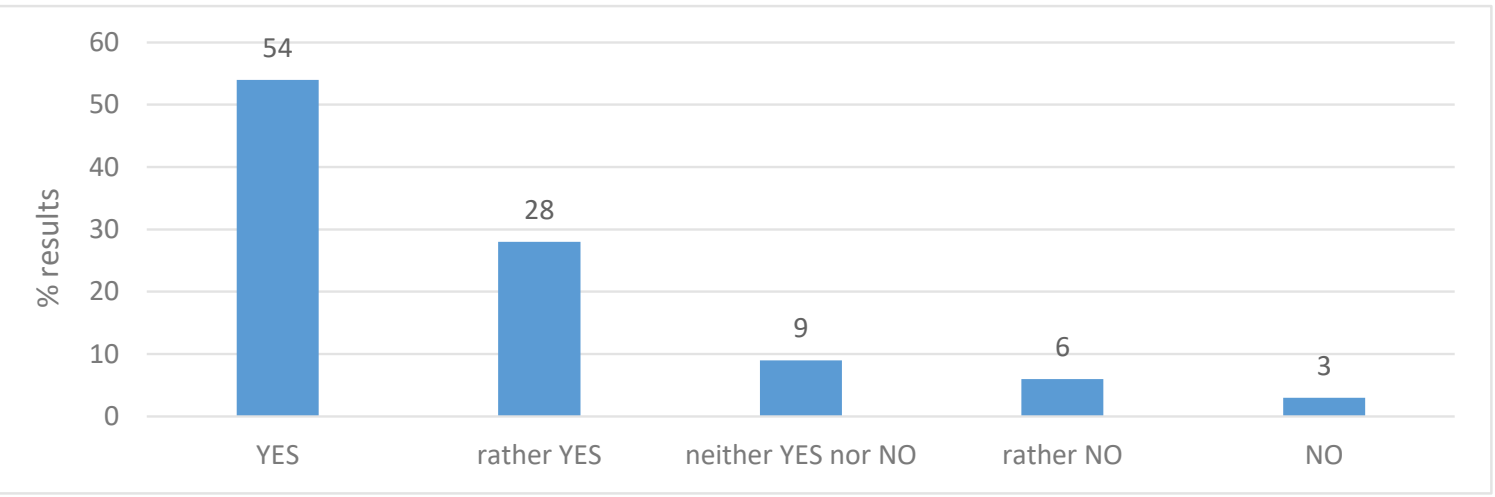

Fig. 1. Do you think that SH system should be used in public buildings and utility services?

The next question concerns the selection criteria, in other words, what the customers consider when deciding to install this system. The divergence of answers can be explained by the variety of installations we deal with and the priorities of the purchaser. Despite a significant drop in the prices of electronic equipment and the general availability of devices included in the $\mathrm{SH}$, the price of the system still remains at the top of the criteria. Other priorities refer to the technical characteristics of the equipment, with particular emphasis on compatibility, sense of security of the home users, and measurable energy efficiency of the building. The financial outlay incurred in equipping a building with technological installations must quickly pay off, which is probably how this group of criteria should be interpreted. 


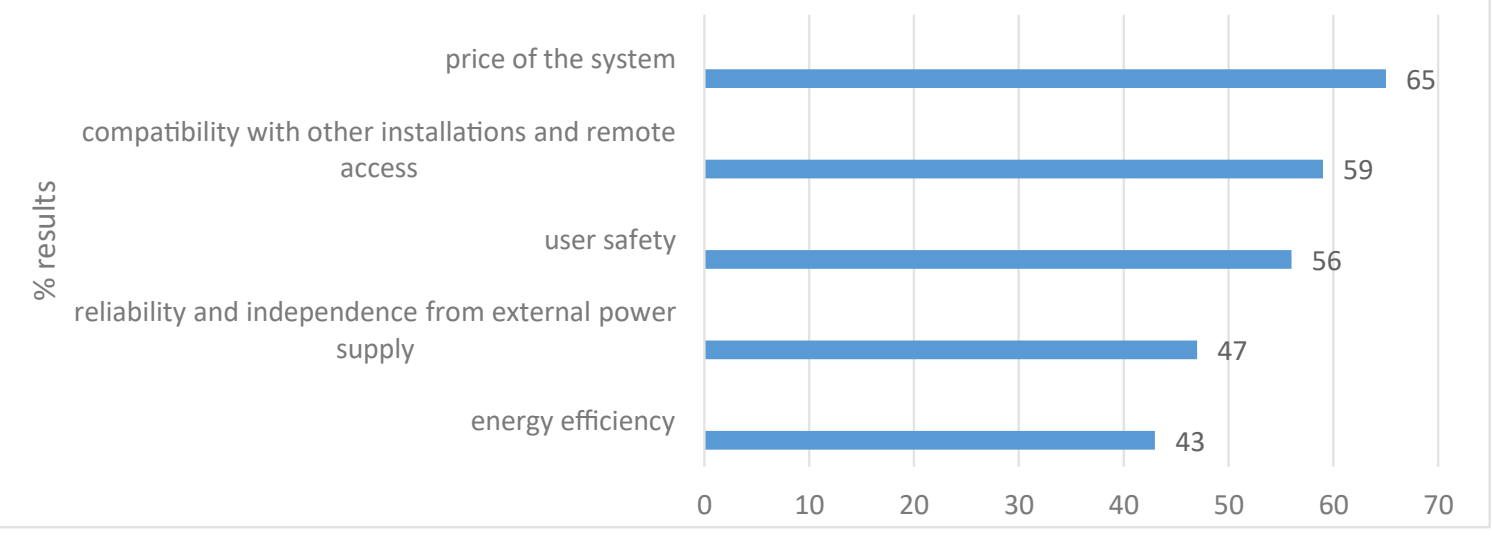

Fig. 2. What are the most important criteria for choosing an SH system?

Another question concerns the possibility of adapting the system to the functional and operational needs of this group of buildings. The author was interested to find out what features the buildings equipped with the SH system should have and what they should inform us about. In the first place in this group of criteria was the information on the number of people in a building or room. This may indeed be an important criterion not only because of the crowding in the interior, but also on the permissible number of people per given area (it might be used in connection to the recent restrictions related to the Covid 19 pandemic). Further criteria mentioned are the broadly understood comfort of the facility and the microclimate created in it (temperature, humidity, lighting, ventilation, etc.) and accessibility for specific users [7]. Just in the same way, personalisation becomes important for consumers, i.e. adapting the facility to individual needs, e.g. interactive tracks for moving around inside, verbal and non-verbal communication with a user.

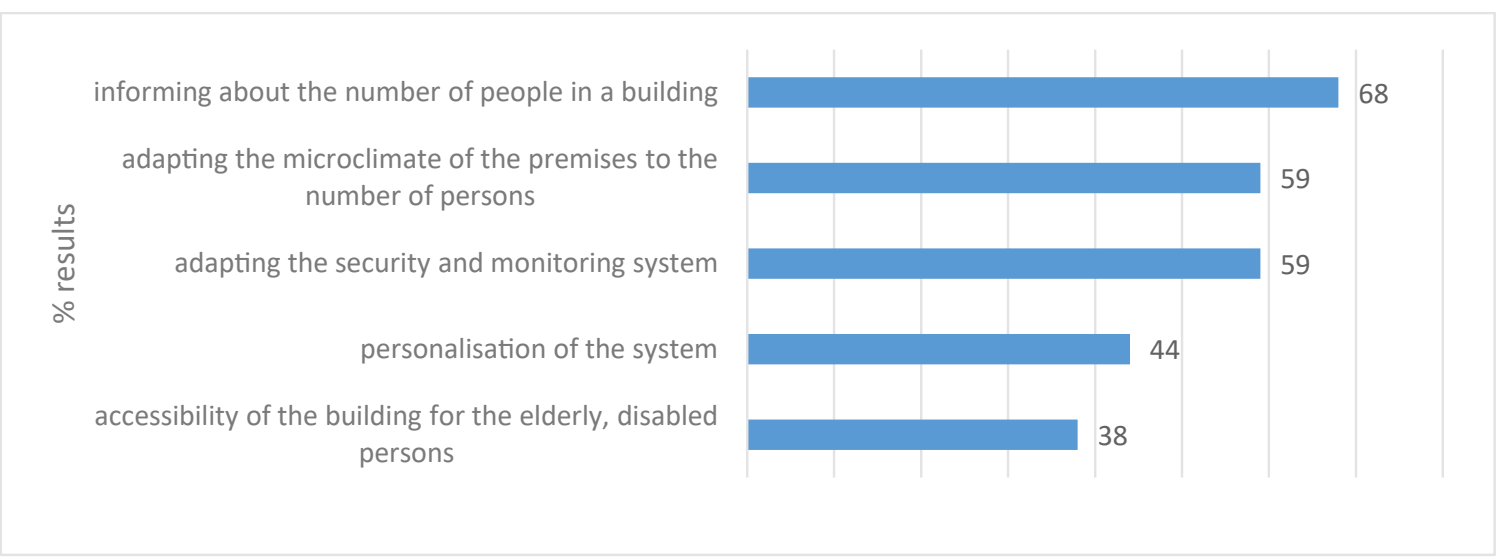

Fig. 3. What are the criteria for adapting smart home features to the needs of public buildings and utility facilities?

The last question concerned the criterion for extending the system in the future, focusing on the characteristics of smart buildings. In other words, what should smart buildings be distinguished by? The answers provided by participants of the survey were very thought-provoking, as some of them emphasised the necessity of using renewable energy as a source of power supply, part of them pointed out the necessity of paying attention to the form and aesthetics of the building, its location and covering the area adjacent to the plot with the system (plants watering, waste management, or creation of biomass for fertilisation). 


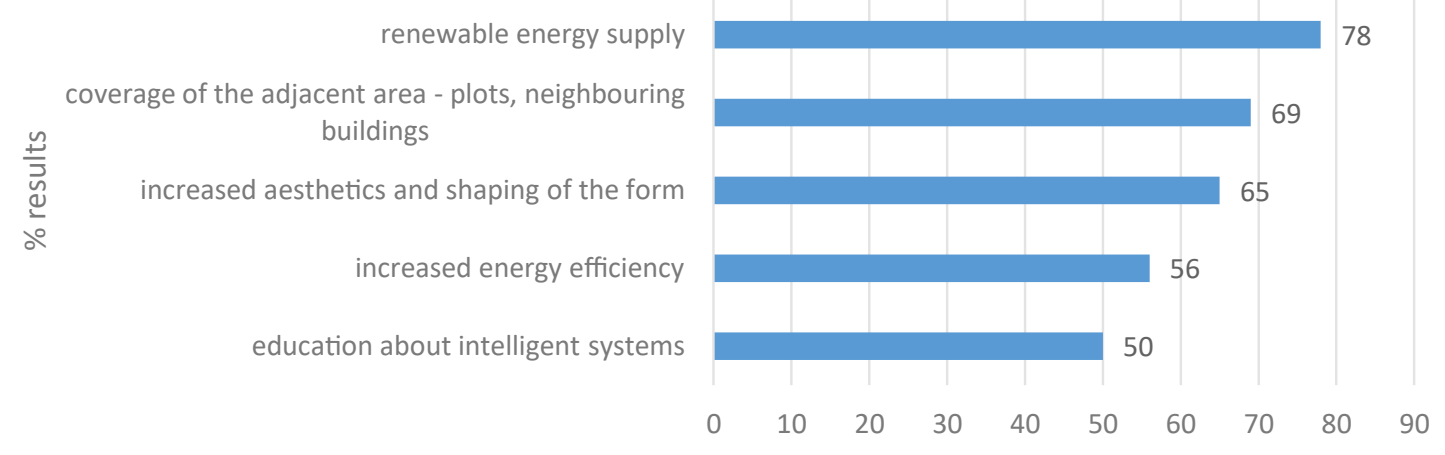

Fig. 4. What are the challenges for the future of the SH system?

\section{Criteria of assessment of smart homes}

The digital and ecological evolution, which is rapidly progressing right before our eyes, forces the necessity to use devices generating clean energy, obtained from natural sources - such as the sun, wind, or water. On the one hand, it is about protecting the environment and, on the other, becoming independent from traditional energy sources. This trend must be the leading one in defining the system development strategy for the following years. Technological development should be considered as civilisational and social development. Therefore, the creation of smart buildings should be perceived as a priority for economic progress, in terms of creating a sustainable environment for human habitation for the nearest future. This may be evidenced by systematic evaluation criteria of the system, presented in the table below.

Table 1. Systematics of evaluation criteria for SH systems

\begin{tabular}{|c|c|c|c|c|}
\hline & $\begin{array}{c}\text { Group of criteria } \\
1\end{array}$ & $\begin{array}{c}\text { Specific criteria } \\
2\end{array}$ & $\begin{array}{c}\text { Constraints and barriers } \\
3\end{array}$ & $\begin{array}{c}\text { Measures } \\
4\end{array}$ \\
\hline 1 & $\begin{array}{l}\text { Architectural and } \\
\text { construction }\end{array}$ & $\begin{array}{l}\text { the shape and form of the } \\
\text { building, } \\
\text { the possibility of } \\
\text { modifying the interiors, } \\
\text { the use of modern } \\
\text { building materials, } \\
\text { structural solutions }\end{array}$ & $\begin{array}{l}\text { lack of education of } \\
\text { planners, } \\
\text { wrong aesthetic patterns, } \\
\text { lack of appropriate legal } \\
\text { acts, } \\
\text { lack of coordination of } \\
\text { planning and investment } \\
\text { activities }\end{array}$ & $\begin{array}{l}\text { increase in the } \\
\text { number of smart } \\
\text { buildings handed } \\
\text { over, } \\
\text { increase in the } \\
\text { number of people } \\
\text { per facility }\end{array}$ \\
\hline 2 & $\begin{array}{l}\text { Ecological and } \\
\text { environmental }\end{array}$ & $\begin{array}{l}\text { installation of renewable } \\
\text { energy systems, contact } \\
\text { with nature, } \\
\text { energy efficiency of } \\
\text { appliances, } \\
\text { use of biodegradable } \\
\text { materials }\end{array}$ & $\begin{array}{l}\text { initial cost of installing the } \\
\text { system, } \\
\text { limited production of } \\
\text { suitable materials, } \\
\text { lack of knowledge and its } \\
\text { dissemination, } \\
\text { lack of promotion }\end{array}$ & $\begin{array}{l}\text { increase in the } \\
\text { ratio of green } \\
\text { and biologically } \\
\text { active areas per } \\
1 \text { inhabitant, } \\
\text { creation of } \\
\text { adequate } \\
\text { legislation }\end{array}$ \\
\hline
\end{tabular}




\begin{tabular}{|c|c|c|c|c|}
\hline & $\begin{array}{c}\text { Group of criteria } \\
1\end{array}$ & $\begin{array}{c}\text { Specific criteria } \\
2\end{array}$ & $\begin{array}{c}\text { Constraints and barriers } \\
3\end{array}$ & $\begin{array}{c}\text { Measures } \\
4\end{array}$ \\
\hline 3 & Technical & $\begin{array}{l}\text { adaptation of the facilities } \\
\text { to the needs of the elderly } \\
\text { and disabled, } \\
\text { provision of power supply } \\
\text { networks to the site, } \\
\text { preference for open } \\
\text { systems that allow for } \\
\text { expansion, } \\
\text { system control from a } \\
\text { smartphone, smartwatch } \\
\text { or tablet }\end{array}$ & $\begin{array}{l}\text { lack of adequately } \\
\text { prepared technical staff, } \\
\text { adaptation of price levels } \\
\text { to consumer needs, } \\
\text { lack of adequate financial } \\
\text { resources }\end{array}$ & $\begin{array}{l}\text { creation of new } \\
\text { technologies, } \\
\text { adaptation of SH } \\
\text { technologies to } \\
\text { user needs }\end{array}$ \\
\hline 4 & $\begin{array}{c}\text { Social } \\
- \text { economical }\end{array}$ & $\begin{array}{l}\text { personalisation of } \\
\text { facilities and tailor-made } \\
\text { installations, } \\
\text { energy saving, } \\
\text { safety of living, } \\
\text { economic accessibility of } \\
\text { equipment and facilities }\end{array}$ & $\begin{array}{l}\text { conflict of interest } \\
\text { between the producer- } \\
\text { seller and buyer, } \\
\text { fear of novelty, } \\
\text { mental and cultural } \\
\text { limitations }\end{array}$ & $\begin{array}{l}\text { creating economic } \\
\text { incentives for } \\
\text { the development } \\
\text { of intelligent } \\
\text { buildings, } \\
\text { education of the } \\
\text { public }\end{array}$ \\
\hline
\end{tabular}

\section{Conclusions}

The presented results of the research indicate the need for further extension of the system with new functions, e.g.:

- Including eco-friendly energy saving devices.

- Personalising new versions of devices.

- Paying more attention to the safety of facilities.

Adjusting the price of products to the economic possibilities of consumers.

Pro-environmental education of students who in the near future will be the people responsible for implementing the available technological solutions can positively influence the promotion of various forms of environmental protection, but also combining them with the digital environment, e.g. in the field of artificial intelligence. Creating clear criteria for assessment of SH system implementation can contribute to wider promotion and construction of facilities that meet future challenges [13]. A notable effect of creating interdisciplinary solutions is that they are easy to use and compatible with other already existing solutions. Continued education on the topic and widespread availability of technological solutions applied through digital devices of general access such as smartphones, smartwatches, and tablets will ensure a tangible effect in the future in the form of energy savings or creation of a friendly living environment. At the same time, we should strive to broaden the interdisciplinary knowledge of designers of technological devices and house designers well beyond the narrow specialisation of their field of study. 


\section{References}

[1] Bergeron F., Bouchard K., Gaboury S., Giroux S., Tracking objects within a smart home, Expert Systems With Applications, 113, 428-442, 2018.

[2] Bin Zhou, Wentao Li, Ka Wing Chan, Yijia Cao, Yonghong Kuang, Xi Liu, Xiong Wang, Smart home energy management systems: Concept, configurations, and scheduling strategies, Renewable and Sustainable Energy Reviews, 61, 30-40, 2016.

[3] Careglio D., Fiore U., Ricciardi S., Sembroiz D., Planning and operational energy optimization solutions for smart buildings, Information Sciences, 476, 439-452, 2019.

[4] Cook D.J., De la Cruz G., Goel S., Minor B., Nesaei S., Pereyda C., Raghunath N., Schmitter-Edgecombe M., Wilson G., Robot-enabled support of daily activities in smart home environments, Cognitive Systems Research 2018.

[5] Darby S.J., Gram-Hanssen K., "Home is where the smart is"? Evaluating smart home research and approaches against the concept of home, Energy Research \& Social Science, 37, 94-101, 2018.

[6] Ford R.,Karlin B.,Pritoni M.,Sanguinetti A., Categories and functionality of smart home technology for energy management, Building and Environment, 123, 543-554, 2017.

[7] Kumard P., Mazaheric M., Morawska L., Salthammer L.C., Salthammer T., Schiewecka A., Uhdea E., Smart homes and the control of indoor air quality, Renewable and Sustainable Energy Reviews, 94, 705-718, 2018.

[8] Lyanage C. De Silva, Morikawa C., Petra I.M., State of the art of smart homes, Engineering Applications of Artificial Intelligence, 25, 7,1313-1321, Elsevier 2012.

[9] Mikulik J., Budynek inteligentny. Podstawowe systemy bezpieczeństwa w budynkach inteligentnych, vol 2, Wydawnictwo Politechniki Śląskiej, Gliwice 2010 (in Polish).

[10] Min Li, Wenbin Gu, Wei Chen, Yeshen He, Yannian Wu, Yiying Zhang, Smart Home: Architecture, Technologies and Systems, Procedia Computer Science, 131, 393-400, 2018.

[11] Niezabitowska E., Metody i techniki badawcze w architekturze, Wydawnictwo Politechniki Śląskiej, Gliwice (2015) (in Polish).

[12] Suriya Priya R. Asaithambi, Sitalakshmi V., Ramanathan V., Big Data and Personalisation for Non-Intrusive Smart Home Automation, MDPI Journal, 5, 6, 1-21, 2021.

[13] Tookey J., Omrani H., Fleury A., Naismith N., Ghaffarianhoseini M., Gaffarianhoseini A., Future of Smart Homes: Application of Intelligent Technologies towards Smaler Urban Future, IGI Global 2016.

[14] City of 2030 survey by Cite Research - November 2018 (2019), 30 July 2021, https://www.plastech.pl/wiadomosci/Urzadzenia-Smart-Home-beda-standardem-do-2030-roku-14192. 